\title{
ASSESSMENT OF THE ADAPTING ABILITIES OF THE CARDIOVASCULAR SYSTEM OF STUDENTS TO PHYSICAL LOAD
}

\author{
Petko Mavrudiev \\ University of National and World Economy, Sofia, Bulgaria
}

\begin{abstract}
In this article the current adaptation abilities of the cardiovascular system (CVS) of 227 students from two faculties of NSA Vassil Levski - Pedagogy and Kinesiotherapy is studied. The research methodology is complex and involves the study of literary sources, testing, mathematical-statistical processing and analysis. For the purpose of the study, a 3-minute standard YMCA load test was conducted. Test results are processed by: variation analysis, frequency analysis and 7-point scale method.
\end{abstract}

Key words: students, adaptation, cardiovascular system, cardiac rhythm.

\section{INTRODUCTION}

In the life of a certain part of the students' sport, which to some extent is an anti-stress factor, takes an important place. Physical activity plays an important role in the formation of body's functional reserves. At the same time in Universities training and competitive activity alongside with the academic load places high demands on the functionality of the body and the health of students. Any discrepancy between the volume as well as intensity of physical activity and adaptive capabilities of the organism can cause a number of changes in functional systems on homeostatic level, change the regulatory-adaptive status of the body, predetermining the further course of adaptation (Bersenev, 2008; Ignatova, 2017).

Sports training loads, in their turn, have a significant impact on the morphofunctional development of the circulatory apparatus and, in particular, of the heart, as well as the usefulness of the mechanisms of its regulation (Tihvinskij, 1991).

According to Phillip B. Sparling (2007), Professor of Applied Physiology, college education is a time during which students develop habits that will be useful to them for life. Some of these habits should include physical activity and sports. This is not only a university task, but it should also be a public policy given the enormous scale of the problem of obesity globally, including America, any assistance in this regard would be helpful, especially when it comes to students. The same author finds that people who are used to exercising as young people are much less likely to suffer from illnesses associated with lack of physical activity as adults. The pres- ence of physical education and sports in university programs is not only important for maintaining a good BMI. Research shows that regular physical activity improves cognitive and decision-making processes, as well as increases overall happiness. (https://greatist.com/fitness/colleges-drop-gymclass-011012).

One of the main mechanisms by which physical activity influences the cardiovascular system during regular exercise is related to its adaptation. In a trained body, the adaptation processes to the workload are much faster and one can work longer without feeling tired. As a result of physical activity, cardiac activity, metabolism, and overall blood circulation are generally improved. The effects that occur in the cardiovascular system, under the influence of physical activity, depend on the intensity, duration and systematic load. The cardiovascular system is most influenced by physical activity, and tests for registering adaptation processes carry objective information about both the adaptive capacity and the physical capacity and health status of the person.

To determine the ability to adapt the cardiovascular system to the physical exertion applied, socalled standard-load tests are used. Functional samples with standard loads are usually for mass application. They are easily applicable in practice due to the availability of physical activity and the lack of special equipment, and the main criterion for functional work capacity is the response of the cardiovascular system, evaluated by the pulse rate 
(HR). The reaction is evaluated by quantitative and qualitative characteristics of reactivity and recovery (Slanchev, 1998, 2014; Petkov, Toteva, Maznev, Dimitrova, 2012).

Functional study of the cardiovascular system for adaptation to physical activity is also done (Pirova, Belova 2001).

In the article "The Functional State of the Cardiovascular System of Students with Different Levels of Physical Fitness" A Konkabaeva and M Rasol, 2016 are researching the current functional state of the cardiovascular system of the body of students that regularly go in for sport and those that are not involved in sports. The cardiovascular system was estimated by recording the heart rate variability, and by defining a work capacity of a man by Rufier method. A complex estimation of heart rate variability by index of activity of the regulatory systems of the body was carried out. It was found that students involved in sports had a moderate and expressed stress on regulatory systems observed in $55 \%$ of cases that composed more than half of the surveyed students. It may be due to inadequate physical load placed on the current functional state of the body.

A similar study, but with the 3-minute standard test of the YMCA's standard workload with students from TU, Sofia, was made by A. Tsarova (2013), who found that training in physical education and sports in higher schools does not lead to increasing the possibilities for adaptation of the cardiovascular system to physical activity, regardless of the nature of the applied motor activities, as well as $\mathrm{P}$. Mavrudiev 2018 with students from the University of National and World Economy.

\section{METHODOLOGY}

The aim of this study is to identify the possibilities for adaptation of the cardiovascular system to the physical loads of students.

The subject of the study is the influence of physical activity on the adaptive capacity of the cardio- vascular system.

The object of the study is the adaptation of the cardiovascular system to physical exertion by students. A total of 227 students, 148 men and 79 women from the NSA from two professional fields, a teacher - 118 men and 59 women and kinesitherapy 30 men and 21 women were included in the study.

The research methodology is complex and involves the study of literary sources, testing, mathematical-statistical processing and analysis (Mackenzie, 2011; Gigova, 2002).

For the purpose of the study, a 3-minute standard YMCA load test was conducted with students from two NSA faculties during the 2017/18 academic year.

Test results are processed by:

$\checkmark$ variation analysis;

$\checkmark$ frequency analysis;

7 -point scale method.

The evaluation of the test results was made on the basis of the achieved heart rate values during the applied standard load conducted a 3-minute standard step test with a metronome by a $30 \mathrm{~cm}$ high step. The logic in determining the estimate is based on the value of the pulse immediately after loading, i.e. the lower the attained heart rate, the better the adaptive capacity of the cardiovascular system and the functional state of the subject to be examined. In assessing the results of our studies, a 7-point scale was used, consistent with the gender of the subjects studied (Petkov, Toteva, Maznev, Dimitrova, 2012).

\section{RESULTS}

The analysis of Table 1 shows that just before the functional test was performed, the average resting heart rate of the studied population of NSA Pedagogy faculty $(\mathrm{PF})$ students was $68.57 \mathrm{~b} / \mathrm{pm}$. for men and $67.55 \mathrm{~b} / \mathrm{pm}$ for women. These are the heart rate values that are within the normal range of the tested population.

Table 1. Average results of a 3-minute step test to determine the adaptive capacity of the cardiovascular system to physical activity - PF of NSA

\begin{tabular}{|l|l|l|l|}
\hline № & \multicolumn{1}{|c|}{ Indicators } & \multicolumn{1}{c|}{ Men } & \multicolumn{1}{c|}{ Women } \\
\hline $\mathbf{1 .}$ & $\mathbf{P}_{\text {rest }}$ & $68,57 \mathrm{~b} . / \mathrm{pm}$ & $67,55 \mathrm{~b} . / \mathrm{pm}$ \\
\hline 2. & $\mathbf{P}_{\text {after }}$ & $81,63 \mathrm{~b} . / \mathrm{pm}$ & $81,89 \mathrm{~b} . / \mathrm{pm}$ \\
\hline 3. & Change - \% & $19,04 \%$ & $21,23 \%$ \\
\hline 4. & Average grade & High & Very high \\
\hline
\end{tabular}


The table shows that, after applying the standard the initial one, and for women - on average by load, the average heart rate for the first minute of $21.23 \%$.

recovery reaches $81.63 \mathrm{~b} / \mathrm{pm}$. for men, up to 81.89 $\mathrm{b} / \mathrm{pm}$ for women. This allows, according to the norms of sports medicine (Petkov, Toteva, Maznev, Dimitrova, 2012), the ability of the cardiovascular system of the studied set of men to adapt to physical activity to be evaluated as high and for women as very high.

The calculated relative share of the observed changes shows that after the loading, the pulse rate for men from the Pedagogy faculty of the National Sports Academy is on average $19.04 \%$ higher than

It is noteworthy that the measured mean pulse rates for men and women at the beginning and end of the step test are very close. This suggests that the ability of future physical education teachers to adapt to physical activity does not depend on their gender.

The analysis of the results presented in fig. 1, reveals the relative proportions of individual assessments of the capacity of the cardiovascular adaptation system for students of the Pedagogy faculty of the National Sports Academy.

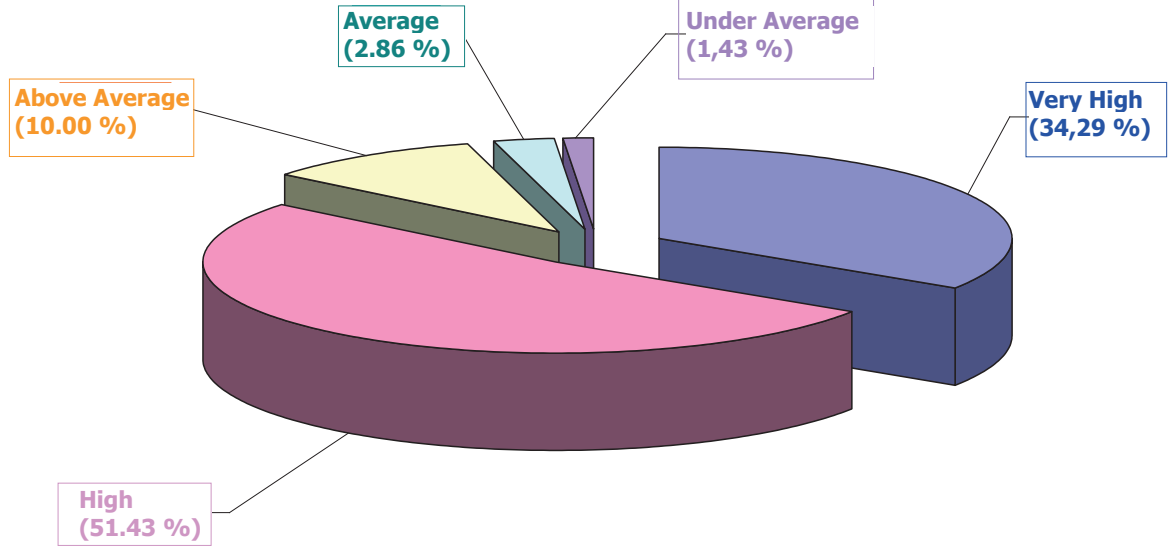

Figure 1. Relative proportions of individual assessments of the cardiovascular system's capacity for adaptation of students from the Faculty of Pedagogy of NSA (men)

The figure shows that the highest (51.43\%) for men is the relative share of high individual scores, and for $34.29 \%$ of them the score is even very high. Only $2.86 \%$ of future physical education teachers have average grades, and below average grades are seen for $1.43 \%$ of the total population. For the purposes of the study, the relative propor- tions of the changes in the pulse rate by zones were also revealed.

The analysis of Figure 2 shows that, as a result of the applied standard load, an increase in the pulse rate within $20 \%$ of the initial one occurred for $55.71 \%$ of the students at the NSA Pedagogy faculty.

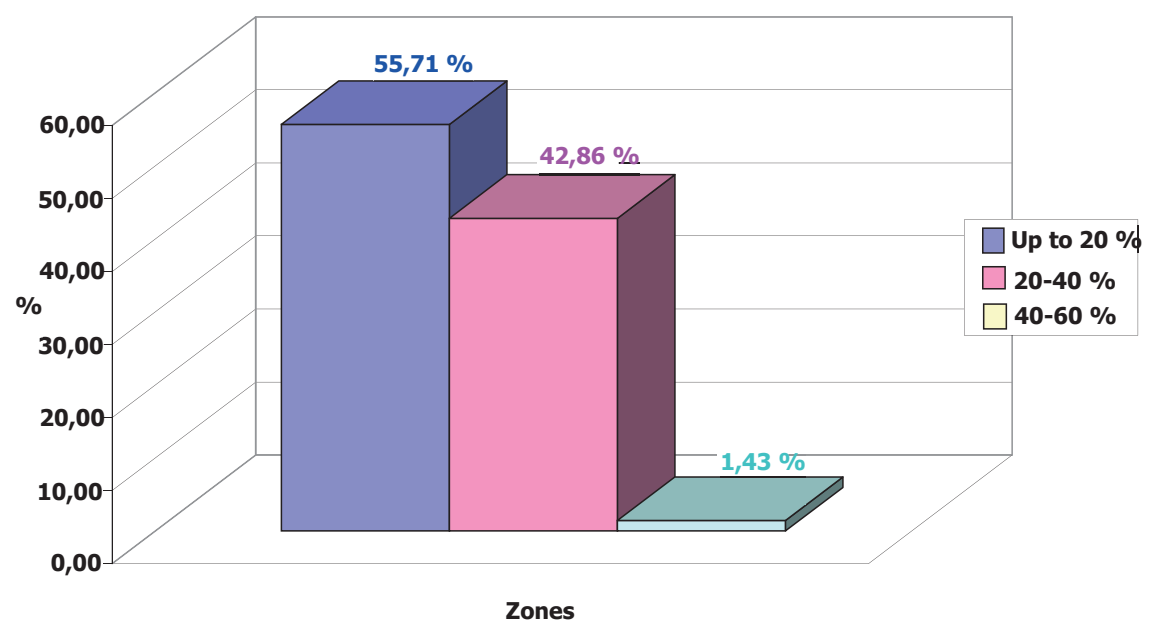

Figure 2. Relative proportions of the changes in heart rate (in \%) by the students from the Faculty of Pedagogy of NSA (men) 
Much lower (42.86\%) is the relative share of those with change between 20 and $40 \%$. Only for $1.43 \%$ of the prospective physical education teachers the applied load caused a pulse rate increase between 40 and $60 \%$.
The relative proportions of individual assessments of cardiovascular adaptation capacity in female students of the Pedagogy faculty of the National Sports Academy are presented on Figure 3.

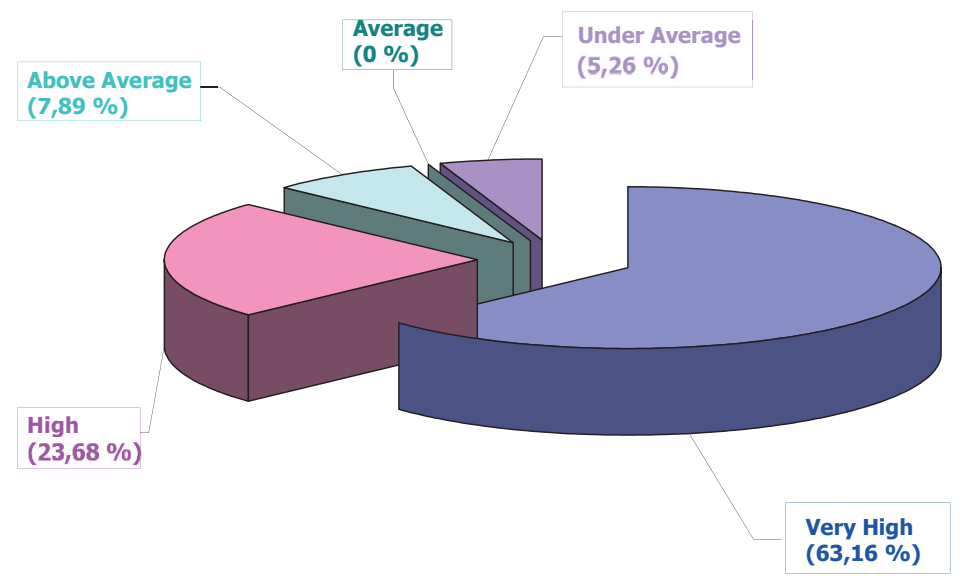

Figure 3. Relative proportions of individual assessments of the cardiovascular system's capacity for adaptation of students from the Faculty of Pedagogy of the NSA (women)

The analysis of the figure shows that over $63 \%$ of The pattern of changes in heart rate by zone in fethe female students of the NSA's PF (women) have male students from this population is very different very high adaptive capacity. They can easily be add- from the one already commented in the men at the ed to about $24 \%$ who have high individual grades. NSA Pedagogy faculty Figure 4.

This is a good sign and it is reasonable to say that, As can be seen from the figure, an increase in the as a whole, the group of future physical education pulse rate within $20 \%$ was observed in $63.16 \%$ of teachers has a high level of functional readiness, the studied population, which is a sign of a high which is a guarantee for good professional reali- level of adaptation of the cardiovascular system to zation in the future. the applied functional load.

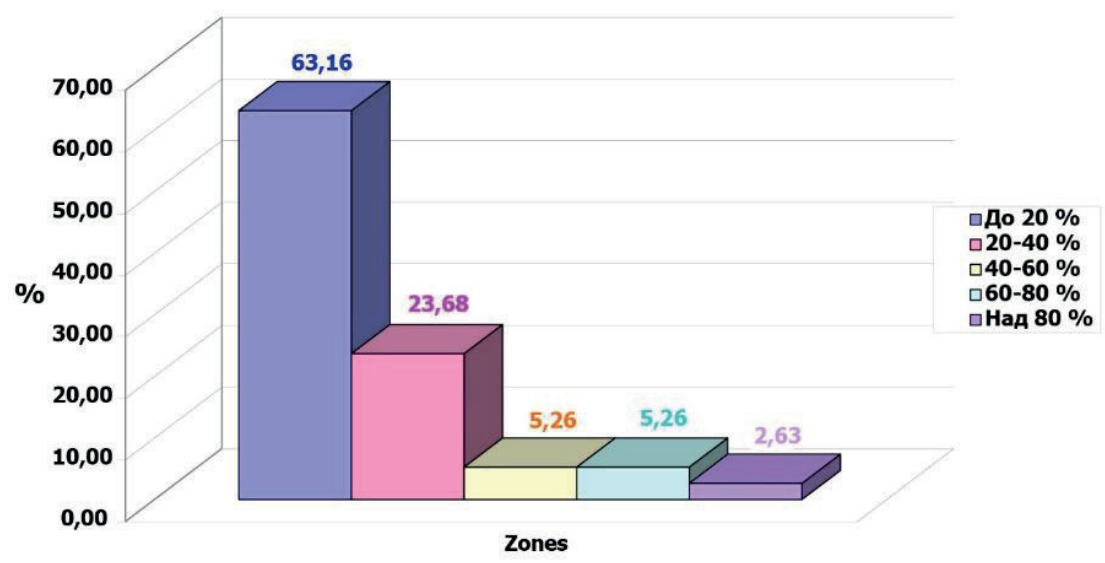

Figure 4. Relative proportions of the changes in heart rate (in \%) by the students from the Faculty of Pedagogy of NSA (women)

Much smaller (23.68\%) is the relative share of fe- extremely strong - the pulse rate reaches over $80 \%$ male students with an increase in heart rate bet- of the initial one. This is evidence of a low level of ween 20 and $40 \%$. Only 5.26\% of them have an in- endurance development for these girls and is likely crease within the next two zones (between 40 and to create problems in the future in the performance $60 \%$ and between 60 and $80 \%$ ). It is noteworthy that of their professional duties as physical education in this group there are female students $(2.63 \%)$, in teachers. whom the response of the applied standard load is 
The results of the conducted step-test with the stu- Levski" are presented on Table 2. dents from the Kinesitherapy faculty of NSA "V.

Table 2. Averages of a 3-minute step test to determine the adaptive capacity of the cardiovascular system to physical activity - NSA Kinesitherapy faculty

\begin{tabular}{|l|l|l|l|}
\hline № & \multicolumn{1}{|c|}{ Indicators } & \multicolumn{1}{c|}{ Men } & \multicolumn{1}{c|}{ Women } \\
\hline 1. & $\mathrm{P}_{\text {rest }}$ & $71,90 \mathrm{~b} . / \mathrm{pm}$ & $74,48 \mathrm{~b} . / \mathrm{pm}$ \\
\hline 2. & $\mathrm{P}_{\text {after }}$ & $86,67 \mathrm{~b} . / \mathrm{pm}$ & $92,86 \mathrm{~b} . / \mathrm{pm}$ \\
\hline 3. & Change - \% & $20,54 \%$ & $24,68 \%$ \\
\hline 4. & Average grade & High & High \\
\hline
\end{tabular}

The analysis of Table 2 shows that just before the result of the applied standard load, are respectively step-test, the average resting heart rate of students with specialty kinesitherapy was $71.90 \mathrm{~b} / \mathrm{pm}$. for men and $74.48 \mathrm{~b} / \mathrm{pm}$ for women. Following standard loading, the average heart rate for the first minute of recovery reaches $86.67 \mathrm{~b} / \mathrm{pm}$ for men and $92.86 \mathrm{~b} / \mathrm{pm}$ for women. This gives grounds for assessing the cardiovascular system's ability for these studied populations (men and women) to adapt to physical exertion as high. $20.54 \%$ for men and $24.68 \%$ for women.

The presented results on Figure 5 allows to reveal the relative proportions of the individual assessments of the possibilities of the cardiovascular adaptation system for the students with specialty kinesitherapy.

The analysis of the results presented in the figure shows that the highest (33.33\%) for men is the relaThe table also shows that the relative proportions of tive share of very high individual grades. the observed changes in the average heart rate, as a

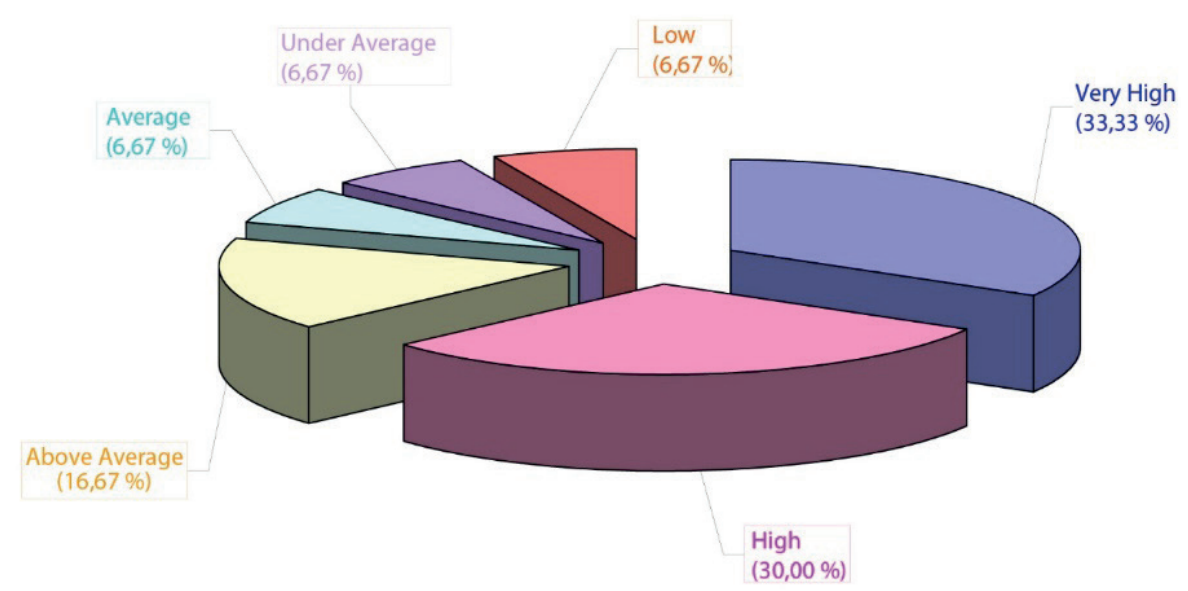

Figure 5. Relative proportions of individual assessments of the cardiovascular system's capacity for adaptation of students from the Kinesitherapy faculty of NSA (men)

Adding to them the high scores of $30.00 \%$, it can be female students from NSA Pedagogy faculty.

concluded that over $63 \%$ of kinesitherapy students The revealed relative proportions of the changes in have a high level of adaptation of the cardiovascular the pulse rate of the kinesitherapy students by zone system to standard physical activities, lasting with- are presented on Figure 6.

in 3 minutes.

From Figure 5 it is also seen that $16.67 \%$ have grades above the average and the relative share of students with grades between low and average is equal to $6.67 \%$. It should be noted here that low inThe analysis of the figure shows that as a result of the applied standard load, for $63.16 \%$ of the students studied in this population, a change in the pulse rate occurred at the end of the impact, with an increase of up to $20 \%$. dividual scores are not observed in both male and 


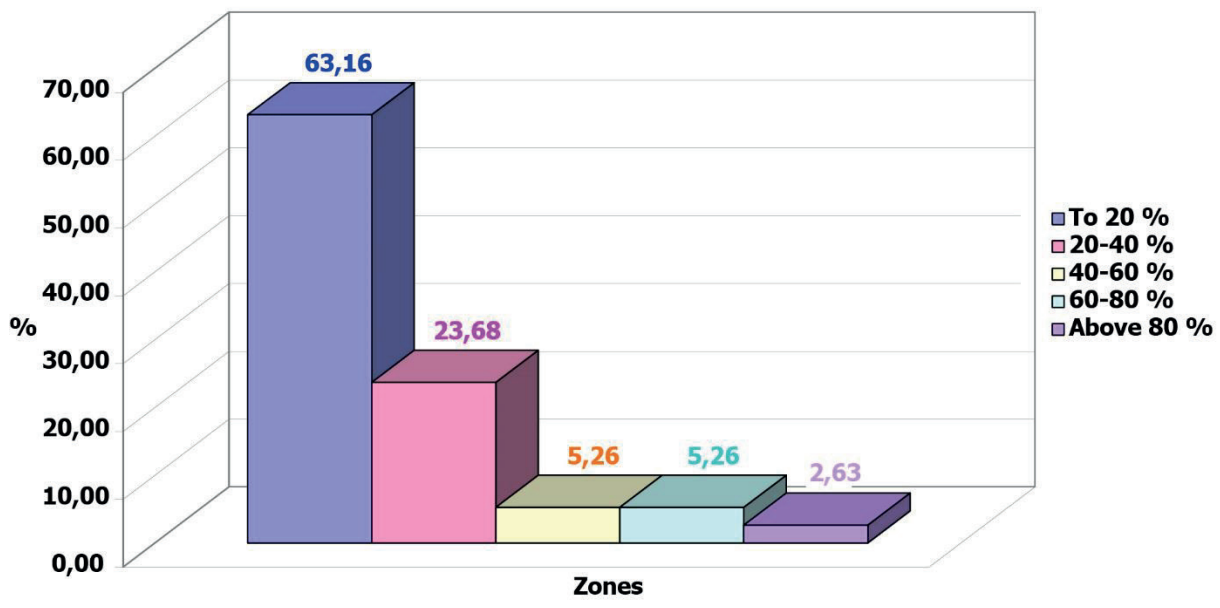

Figure 6. Relative proportions of the changes in heart rate (in \%) by the students from the Kinesiotherapy faculty of NSA (men)

Much lower (23.68\%) is the relative share of those with an increase in heart rate within the range of 20 to $40 \%$. In contrast to men from Pedagogy faculty, in those from Kinesitherapy faculty, the relative proportion of pulse rates reaching between 40 and $60 \%$ at the end of the load is almost 4 times higher $(5.26 \%)$. At the same time, $5.26 \%$ of them reach a heart rate that is $60-80 \%$ higher, and at $2.63 \%$ even higher than $80 \%$. This is a alarming finding. The fact that the body of about $13 \%$ of future kinesitherapists reacts strongly to the applied 3-minute load is evidence of the low level of development in these students of general endurance and the low adaptive capacity of their cardiovascular system.

The results of the kinesitherapists are presented on Figure 7. From the figure it is clear that with high and very high individual grades here are in total over $70 \%$ of the students studied (respectively $38.10 \%$ - high and $33.33 \%$ - very high), which is a sign of a high level of development of functional capabilities for these girls.

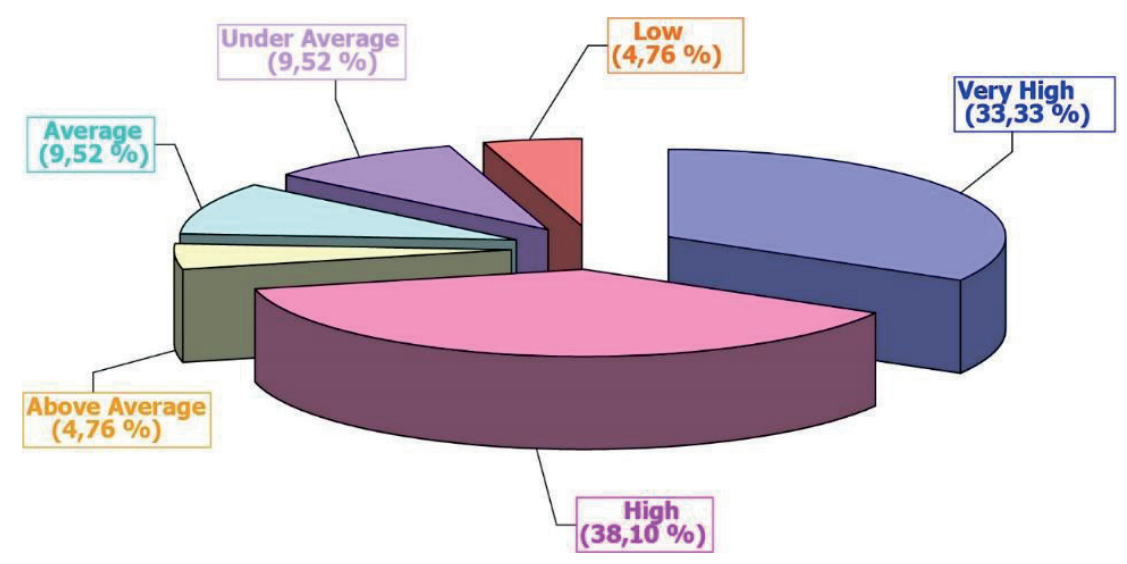

Figure 7. Relative proportions of individual assessments of the cardiovascular system's capacity for adaptation of students from the Kinesiotherapy faculty of NSA (women)

At the same time, however, $9.52 \%$ of the female students in this population have below-average individual grades, and $4.76 \%$ have low grades. In comparative terms, it should be remembered that low scores are not observed in NSA Pedagogy faculty girls. Moreover, the relative share of low grades in future kinesitherapists is higher (6.67\%). This gives the right to be considered that the girls from the
NSA Kinesitherapy faculty showed a higher level of functional adaptation than the boys from the same faculty.

From Figure 8 it is seen that an increase in the pulse rate within $20 \%$ is observed in almost half of the girls included in this group (47.62\%), which is evidence of the high level of cardiovascular ad- 
aptation abilities to the applied functional load. A of $40-60 \%$, but at the same time at $9.52 \%$ the pulse little lower $(38.10 \%)$ is the relative share of female rate increases, as a result of the applied effect, by students, with an increase in heart rate between $20 \quad 60-80 \%$. and $40 \%$. Only $4.76 \%$ of the increase is in the range

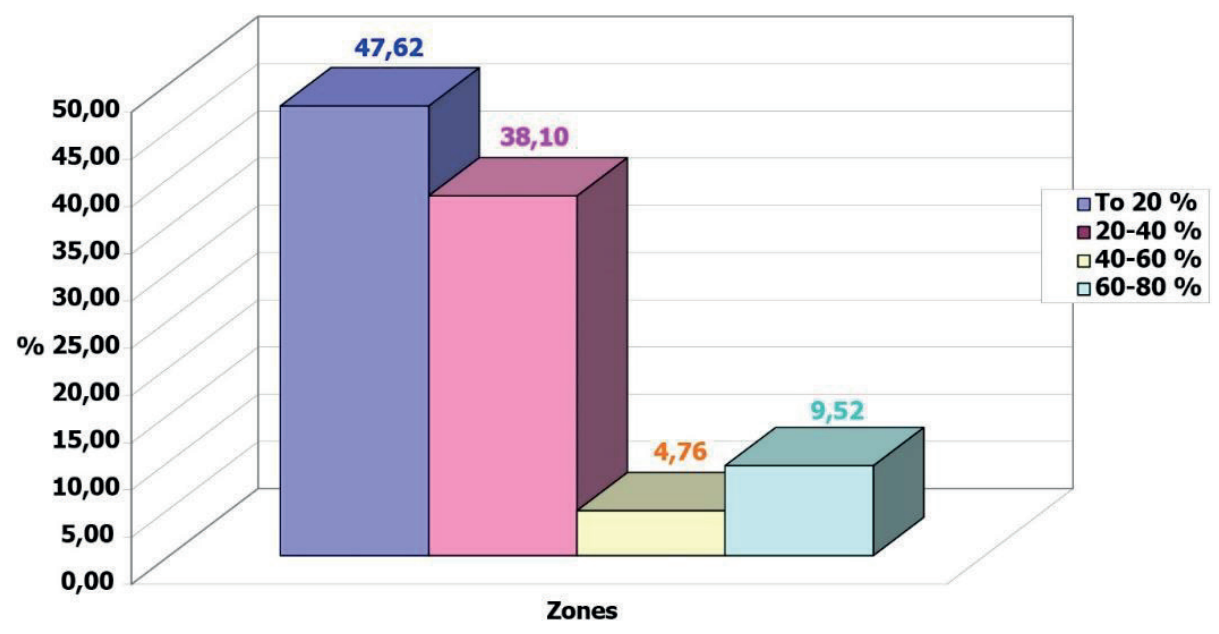

Figure 8. Relative proportions of the changes in heart rate (in \%) by the students from the Kinesitherapy faculty of NSA (women)

\section{CONCLUSIONS}

We can summarize that the response of the cardiovascular system to the applied standard load is adequate to the level of training of all students, regardless of their gender. Proof of this are the individual estimates of heart rate measured within the first minute of recovery.

For students with a teacher qualification after applying the standard load, the average heart rate for the first minute of recovery reaches $81.63 \mathrm{~b} / \mathrm{pm}$. for men, up to $81.89 \mathrm{~b} / \mathrm{pm}$ for women, which determines the ability of the cardiovascular system to adapt to the physical exertion of the study population, men are rated as high and those of women as very high.

By men, $51.43 \%$ is the relative share of high individual scores, and $34.29 \%$ of them is even very high. Only $2.86 \%$ of future physical education teachers have average grades, and below average grades are seen for $1.43 \%$ of the total population.

More than $63 \%$ of female students at the NSA Pedagogy faculty (women) have very high adaptation skills, and about $24 \%$ have high individual grades.

For students with kinesitherapy qualification after the standard load applied, the average heart rate for the first minute of recovery reaches $86.67 \mathrm{~b} /$ $\mathrm{pm}$ for men and $92.86 \mathrm{~b} / \mathrm{pm}$ for women. This gives grounds for evaluating the ability of the cardiovascular system of these study groups (men and women) to adapt to physical activity as high.

By men, $33.33 \%$ is the relative share of very high individual grades, and $30.00 \%$ high marks, it can be concluded that over $63 \%$ of kinesitherapy students have a high level of adaptation of the cardiovascular system to standard physical activities, $16,67 \%$ have grades above the average, and the relative share of students with grades between low and average is equal - $6,67 \%$.

For women with high and very high individual grades, a total of over $70 \%$ of female students (respectively $38.10 \%$ - high and $33.33 \%$ - very high), $9.52 \%$ of female students in this group have individual grades below average, and $4.76 \%$ have low grades.

\section{REFERENCES}

Bersenev, (2008). Bersenev E.Ju. Sportivnaja specializacija i osobennosti vegetativnoj reguljacii serdechnogo ritma [Sports specialization and peculiarities of vegetative regulation of heart rhythm] / Variabel'nost' serdechnogo ritma: teoreticheskie aspekty i prakticheskoe primenenie: tez. dokl. IV Vseros. simp. Izhevsk, 2008. S. 42-45. 
Gigova, V. (2002). Statisticheska obrabotka I analiz na Danni, Sofia, NSA-IPB. // Гигова, B. (2002). Статистическа обработка и анализ на данни. София, НСА - ИПБ, 2002

Ignatova, M. (2017). Izsledvane na efekta ot dvigatelni komplexi vurhu fizicheskata godnost na studentki ot UNSS, Diseracia, NSA “V. Levski” - Sofia // Игнатовва, M. (2017). Изследване на ефекта от двигателни комплекси върху физическата годност на студентки от УНСС, Дисертация, НСА "В. Левски”- София

Konkabaeva, A. E., Rasol, M. (2016). The Functional State of the Cardiovascular System of Students with Different Levels of Physical Fitness. European Journal of Physical Education and Sport. ISSN: 2310-0133 E-ISSN: 2310-3434 Vol. 11, Is. 1, pp. 10-16

Mackenzie, B. (2011). 101 testa za ocenka na fizicheskata godnost. BINS, pp. 27, prevod D. Stefanova // Маккензи, Б. (2011). 101 теста за оценка на физическата годност. БИНС, стр.27, превод Д. Стефанова.

Mavrudiev, P. (2018). Fizichesko razvitie I deesposobnost na student, Disertacia, SU Sv. Kliment Ohridski, Sofia // Маврудиев, П. (2018). Физическо развитие и дееспособност на студенти, Дисертация, СУ Св. Климент Охридски, София

Mavrudiev, P. (2018). Izsledvane adaptaciata na surdechno-sudovata Sistema kum fizicheski natovarvania pri student, Sport I nauka, br. 5, pp. 42-50, ISSN 1310-3393 // Маврудиев, П. (2018). Изследване адаптацията на сърдечно-съдовата система към физически натоварвания при студенти, Спорт и наука, 2018, бр.5, стр. 42-50, ISSN 1310-3393

Petkov, S., Toteva, M., Maznev, I., Dimitrova, D. (2012). Prakticheski uprajnenia po sportna medicina. Uchebno pomagalo za studenti ot NSA, chast 1, Sofia, NSA Press // Петков, С., Тотева, М., Мазнев, И., Димитрова, Д. (2012). Практически упражнения по спортна медицина. Учебно помагало за студенти от НСА, част I, София, НСА Прес.
Piryova, B., Belova, N. (2001). Funkzionalno izsledvane na surdechno-sudovata Sistema za adaptacia kum fizichesko natovarvane. Sport I nauka, br. 5, pp.3142 // Пирьова Б., Белова, Н. (2001). Функционално изследване на сърдечно-съдовата система за адаптация към физическо натоварване. Cnopm $u$ наука, 2001, бр.5, стр.31-42.

Slanchev, P. (1998). Sportna medicina: Sofia, Novi znania //Сльнчев, П. (1998). Спортна медицина. София, Нови знания.

Slanchev, P. (2014). Sportna medicina: Uchebnik za student ot NSA. Novi znania // Слънчев, П. (2014). Спортна медицина, учебник за студенти на НCA, Нови знания.

Sparling, P B. (2007). Obesity on Campus. https://www. ncbi.nlm.nih.gov/pmc/articles/PMC1955391/.

Tihvinskij S.B. (1991). Vlijanie sistematicheskih zanjatij sportom na sistemu dyhanija sportsmenov [Influence of systematic sports on the respiratory system of athletes] // Detskaja sportivnaja medicina. M.: Medicina, pp. 119-127.

Tzarova-Vassileva, A. (2013). Vlianie na zanimaniata s razlichni vidove sport vurhu fizicheskoto razvitie I rabotosposobnostta na student, Disertacia, VTU "Sv. Sv. Kiril I Metodii”, V.T. // Църова - Василева, А. (2013). Влияние на заниманията с различни видове спорт върху физическото развитие и работоспособността на студенти, Дисертация, ВТУ “Св.Св.Кирил и Методий”, В.Т.

Why Colleges Around America Are Dropping PE Requirements https://greatist.com/fitness/colleges-dropgym-class-011012. (accessed on Sept. 10 ${ }^{\text {th }}, 2019$ )

\section{Corresponding author:} Petko Mavrudiev, PhD University of National and World Economy 1117 Sofia, Bulgaria petkomavrudiev@gmail.com 